\title{
ダイコンの色の遺傳研究 (II)
}

建 部民雄

\section{1. 緒言}

第 1 報に於て筑者(1937)は，ダイコンの根の靑頸は白頸に，赫は白に，紅條 は白飞對し, 夫љ 1 遗傳子優性なるとと, 紅條は赫に對して等位にあり, 赤 $(R)$, 紅條 $\left(R^{s}\right)$, 白 $(r)$ の 3 遺傳子は複對立因子であらうと述べた。然ると其の後研 究の進捗と共に，第 1 報の內容に一部補正の必要を生じ，又一方紅心青と他色 との關係も略: 明らかになつたから, 本報に於ては是等について記述し, 最後 そダイコンの根色の遗傳子型とついても論じようと思ふ。份本報內容の誤僇に 關し，御指摘御教示下されば幸甚である。

\section{2. 實 驗 成 績}

\section{（1） 赤 $\times$ 白}

赤四十日 $\times$ 聖護院，赫四十日 $\times$ 大和白上り，赤聖 $\times 小$ 瀨获。

第 1 報に於ては，赤 $\times$ 白の $\mathrm{F}_{1}$ の根色は赤紫色であるが，色調は個體により 變異が多い。 $\mathrm{F}_{2}, \mathrm{~F}_{3}$ は赤い親植物の如き純粹の赤, 及び $\mathrm{F}_{1}$ の如き赤紫色の のを併せて赤と看做すと，赤 3 : 白 1 比の分離を示すととを報じを。元來ダイ コンの根色は環境の影響による色調の變買が著しいてと，及び $\mathrm{F}_{1}$ 飞らはれ る赤紫色も，ハツカダイコンの赤×白の $F_{1}$ にあらはれる紫の如く顯著なも のではないから，赤，赤紫を一括して考へるてとは，一應の說明としては敢て 不可でをいと思はれた。然るに篗者（1938）は其の後ハツカダイコンの赤×白 のF $F_{1}$ は紫で， $\mathrm{F}_{2}$ 壮紫 $9:$ 赤 $3:$ 白 4 比の分離を示すととを知つた。郎ち赤 の遗傳子 $R$ 之，單獨では色をあらはさないが， $R$ と共存すると紫色をあらはす

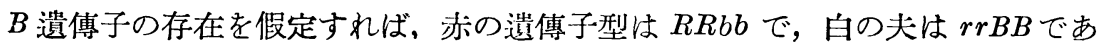
る。從つてダイコンの赤 $\times$ 白の $\mathrm{F}_{2}$ 分離も，赤と赤紫とを區別して再檢討する必 要がある。第 1 報所載の赤四十日 $\times$ 聖萑院 $\mathrm{F}_{3}$ の 1 組, 及び新しい組合せ赤四 十日 $\times$ 大和白上り $F_{2}$ をか〉る觀點より再吟味して第 1 表の如き成績を得を。 
第 1 表 赤と白との雜種第 2,3 代

\begin{tabular}{|c|c|c|c|c|c|}
\hline 次 & 襍 種 組 合 & 赤紫 & 赤 & 白 & 計 \\
\hline $1936 \sim 1437$ & \multirow{2}{*}{$\begin{array}{l}\text { 赤四十日 } \times \text { 聖護院 } \mathrm{F}_{3} \\
\text { 赤四十日 } \times \text { 大和白上り } \mathrm{F}_{2}\end{array}$} & 138 & 42 & 71 & 251 \\
\hline 1938 1939 & & 91 & 36 & 46 & 173 \\
\hline \multicolumn{2}{|r|}{ 計 } & 229 & 78 & 117 & 424 \\
\hline \multicolumn{2}{|c|}{$9: 3: 4$ としての理論數 } & 238.5 & 79.5 & 106 & \\
\hline
\end{tabular}

第 1 表によ ると是等の成 績は，ハツカ ダイコンの夫 の如く, 赤紫 $9:$ 赤 $3:$ 白 4 比の分離とみ られる。從つてての場合の遺傳子型も赫は $R R b b$ で，白は $\operatorname{rr} B B$ であらうと 思はれる。

次に赤琹 $\times$ 小瀨荣の組合せと就いて述べよう。赤聖といふののは第 1 報にも記 して置いた樣に根の外皮赤(淺緋)，肉は根頸部まで白色で，葉柄葉脈の色も赤 (淺緋)である。ダイコンの種子色は何れも褐色（武茶色）であるが，本品種の 種子色は黃色（玉蜀禁色）である。供試系統の $\mathrm{S}_{1}$ (自殖第 1 代目) 71 個體, $\mathrm{S}_{2} 45$ 個體， $\mathrm{S}_{3} 35$ 個體， $\mathrm{S}_{4} 43$ 個體とも色調は固定して居た。赤聖を自殖する と, 次代の一部は正常の綠葉に比し葉綠素の含量少く, 黃綠色を呈して發育狀 態不良, 著しく矮性となり, 生育中に大部分枯死する個體が認められた (chlorina)。是等の中には個體により葉緑素の含量も稍々多く, 永く生存して極めて 貧弱ながら抽薹するものもあつた。 $\mathrm{S}_{4}$ に就いてての點を正確に檢すると, 綠 葉 34 : 黃綠葉 9 の比に分離せるととを知つた。小瀨荣といるのは根頸淡綠色 で，根身は白色である。 $\mathrm{S}_{1} 35$ 個體は根頸淡綠色，又は白色であつたから，根 頸の淡綠色はへテロであつたと考へられる。種子色は勿論褐色である。

赤聖 $\times$ 小瀨荣の $\mathrm{F}_{1}$ は正常の綠葉を有し, 根頸外皮赤紫色(梅紫)で, 下部は 次第に淡色となり，某柄中肋も亦赤紫色であつた。台種子色は褐色であつた。

第 2 表 黄綠葉と綠葉との雜種第 2,3 代

\begin{tabular}{|c|c|c|c|c|}
\hline 年 次 & 雜 種 組 合 & 綠葉 & 黃綠薬 & 計 \\
\hline 1938 & 赤聖 $\times$ 小瀨荣 $\mathrm{F}_{2}$ & 244 & 60 & 304 \\
\hline 1939 & 赤聖 $\times$ 小瀨荣 $\mathrm{F}_{3}$ & 241 & 81 & 322 \\
\hline
\end{tabular}

$\mathrm{F}_{2}, \mathrm{~F}_{3}$ に於ける葉色の分離は第 2 表の通りであつた。

第 2 表によると，黃綠葉は綠 葉に對して 1 遺傳子劣性である と考へられる。との形質は赤聖

（1）括弧內は和田三造編「色名總鑑」による, 以下之に倣子 
中にヘテロの狀態で存したものであらう。少ての黄綠葉 (chlorina) は，星加氏 （1938）によつて研究されたダイコンの albino とは別個のものであり，符者 (1938) のハツカダイコンの xantha ともよく類似して居るが文別個の\&のであ ると考へられる。

根色の分離は第 3 表の通りでむつた。

第 3 表 赤と昌との雜種第 2,3 代

\begin{tabular}{|c|c|c|c|c|c|}
\hline 年 次 & 新種 組 合 & 赤紫 & 赤 & 白 & 計 \\
\hline $1938 \sim 1939$ & 赤聖 $\times$ 小濑荣 $\mathrm{F}_{2}$ & 133 & 76 & 27 & 236 \\
\hline 1939 & 赤聖 $\times$ 小瀨荣 $\mathrm{F}_{3}$ & 200 & 64 & 58 & 322 \\
\hline
\end{tabular}

第 3 表中 $\mathrm{F}_{2}$ の分 離は種子色を多淤せ 檢する目的で，翌年 6 月に入り調査した 爲飞，前記黃綠葉個 體は大部分枮死して居たので，非常に分離比が镝された。 $\mathrm{F}_{3}$ は 12 月上旬に調 查したものであるが，少豫期の赤紫 $9:$ 赤 $3:$ 白 4 比からは可なり大なる偏差 を示して居る。第 1 報に記載しを赤聖 $\times$ 練馬 $\mathrm{F}_{2}$ の分離に於ても，12月に調 查したのであつたが，白が過少となつて居た。種子色，及び根色と種子色とを 考虑した場合の $\mathrm{F}_{2}$ 分離は，第 4 表，第 5 表の通りであつた。

第 4 表 黄色種子と褐色種子との雜 種第 2 代 (1938～1939)

\begin{tabular}{|c|c|c|c|}
\hline 椎種組 合 & $\begin{array}{l}\text { 褐色 } \\
\text { 種子 }\end{array}$ & $\begin{array}{l}\text { 黃色 } \\
\text { 種子 }\end{array}$ & 計 \\
\hline 赤瑟 $\times$ 小瀨荣 $\mathrm{F}_{2}$ & 144 & 92 & 236 \\
\hline
\end{tabular}

上記の如く黃綠葉個體は當時殆ぼ枮 死して居たから，是等の分離比は非常 に筒されて居るものと考へられる。從 つて玆で分離比を檢討するてとは不可

第 5 表 赤色根黄色種子と白色根褐色種子との雜種第 2 代(1938～1939)

\begin{tabular}{|c|c|c|c|c|c|c|c|}
\hline 雜種 組 合 & $\begin{array}{l}\text { 赤紫根 } \\
\text { 褐種子 }\end{array}$ & $\begin{array}{l}\text { 赤紫根 } \\
\text { 共種子 }\end{array}$ & $\begin{array}{l}\text { 赤 根 } \\
\text { 褐種子 }\end{array}$ & $\begin{array}{l}\text { 赤根 } \\
\text { 黃種子 }\end{array}$ & $\begin{array}{l}\text { 香根 } \\
\text { 褐種子 }\end{array}$ & $\begin{array}{l}\text { 帛根 } \\
\text { 黃種子 }\end{array}$ & 計 \\
\hline 赤聖 $\times$ 小瀨荣 $\mathrm{F}_{2}$ & 119 & 14 & 3 & 73 & 22 & 5 & 236 \\
\hline
\end{tabular}

能であるが，第 5 表の成績によつて判斷すれば，種子色に關與せる淟傅子は， 根色儿關與せる夫とは别倜のものであるとと丈は確言出來ると思ふ。

\section{（2）紅條×赤}

紅條 $\times$ 赤四十日，赤四十日 $\times$ 紅條。

既述の如く第 1 報に於ては，紅條×赤の $\mathrm{F}_{1}$ の根色は，上部は赤で，下部は 次第に淡色となり，紅條汃顯著にあらはれた。F，に於ては赫及び赤紅條 $3:$ 紅 
條1の分離比を示した。從つて赤の遺傳子 $(R)$ と, 紅條の遗傳子 $\left(R^{s}\right)$ とは等位 飞あるものと考へられた。又赤 $\times$ 白，紅條 $\times$ 白，紅條 $\times$ 赫が何れも $\mathrm{F}_{2}$ 亿單性 雜種比の分離を示したから, 赤, 紅條, 白に關與する遗傳子 $R, R^{s}, r$ は複對 立因子の一組を構成するものと考へられた。紅條 $\times$ 赤四十日 $\mathrm{F}_{2}$ の分離比は, 當時赤及び赤紅條 $3:$ 紅條 1 としてあらはしたが，理論上は赤 $1:$ 赤紅條 2 : 紅條 1 比にあらはれる筫である。ての點を閭明せん爲に同一組合せの交雜を反 復して，其の $F_{2}$ 亿於て第 6 表の如き結果を得を。

第 6 表 紅條と赤との雜種第 2 代 (1938～1939)

\begin{tabular}{|c|c|c|c|c|}
\hline 猚 種 組 合 & 赤 & 赤紅保 & 紅 條 & 計 \\
\hline 紅條 $\times$ 赤四十口 $\mathrm{F}_{2}$ & $75(6)$ & 147 & 77 & 299 \\
\hline 赤四十日 $\times$ 紅條 $\mathrm{F}_{2}$ & $53(1)$ & 85 & 46 & 184 \\
\hline 計 & 128 & 232 & 123 & 483 \\
\hline $1: 2: 1$ としての理論數 & 120.75 & 241.5 & 120.75 & \\
\hline
\end{tabular}

第 6 表によれば, 是等の成績は嶑期の 如く, 赤 $1:$ 赤紅條 $2:$ 紅條 1 比の分離 と思はれる。们表中 括弧內數字は, 根部 の赤色淡く，白を思

はせる個體數である。然し是等も葉柄恃明らかに赤色であつたから, 赤と看做 して差支ないものと思はれた。ての關係を一膡確めんが爲に, 紅條×赤四十日 $F_{2}$ の赤色個體中，一見白色個體と思はれ女のを自殖して次代を檢したとてろ， 根頸部赤, 葉柄中肋赤の 多の 130 個體, 根頸部淡綠, 葉柄中肋赤の 8 の 13 個 體を得たっ從つて前年白ではないかと疑つたものも，赤であつたととが確實と なつた。之によるとダイコンの根色は變異が著しいから, 赤と思はれるもので をと八根部の赤色が淡くとも, 葉两中肋が赤色色素を有するものは, 赤と看做 して差支ないものと考へられる。

元來紅條は根身は白で, 側根の發生部に赤紫色(梅紫)の橫條を有するもので あるから， $R^{s}$ 遺傳子の外飞必亦前記の $B$ 逼傳子を有するものと考へられる。 然し上祀の分離比は $R^{s}$ と $R$ のみを考虑し， $B$ は度外視してある。（ $B$ 遗傳子 の作用を考虑し, 上記の赤, 赤紅條, 紅條を更に各こ赤色と赤紫色とに分けて 分離比を檢行すると， $R^{s}$ と $B$ との間聯關が存するのではないかと思はれる 成績を得たが，色調の變異が多かつたから，茲には確言出來ない)。

（3）紅心靑及び其の自殖成績 
紅心靑といふのは，植物體各部の中心杜維管束部に赤色色素を有する珍しい 品種である。師ち根の肉色は美しい放射狀の赤色 (菌色) で, 根頸外皮は綠色 (荣種油色)を呈して居る。乙れ紅心靑の名ある所以である。佮蕉，葉柄の維管 束や，枼脈，花瓣にも赤色色素を有して居る。又との品種は系統により色調に 可なりの變異が觀られた。

紅心青の異常遺傳に就いての研究は，夙に宗，今井及び寺濢 3 氏 (1919) に よつて發表され，其の後今井氏（1934）により，夫は紅心青 $\rightarrow$ 白への轉化を示 す易變因子なることが論ぜられた。

紅心靑の自殖にあたつては，2 系統を用ひた。一つは青頸赤肉のものであ り，假にA系と稱する。A 系は更に AI, AII, AIII の 3 系に區別する。他は外 皮肉ともに紫色のものであり，乙れを B系と呼ぶととつする。AI 系の $\mathrm{S}_{1} 80$ 個體は何れも赤肉に固定し， $\mathrm{S}_{2} 30$ 個體， $\mathrm{S}_{3} 42$ 個體とも赤肉に固定して，白 を分離することはなかつた。次と AII 系の $\mathrm{S}_{1} 64$ 個體中，63 個體は赤肉で， 只 1 個體のみ白肉之思はれる に固定して居た。これに反してB系は $\mathrm{S}_{1} 37$ 個體中，21 個體は紫肉又は赤肉 で，16 個體は白肉飞分離し， $\mathrm{S}_{2} 42$ 個體名紫肉又は赤肉 24 : 白肉 18 亿分離 した。份ての場合は種子の不發芽に終つたものが可なりあつたととを附記す る。

今紅心靑に關與する遗傳子を $R^{f}$ とすれば，A系は $R^{f} R^{f} b b$ といふホモのも のであり，B系は $R^{f} r B b$ といふへテロのものであつたと思はれる。後述の如 く紅心靑 $\mathrm{A}$ 系 $\times$ 白の $\mathrm{F}_{1}$ が，根の外皮肉とも紫色であり，蓕葉其の他飞紫色を 帶べる事實よりみててれは確實である。文 $B$ 系の自殖後代に於ては， $R^{f} r$ の $R^{\top}$ が $r$ 人因子轉化を行ふ爲に, 赤肉 3 ：白肉 1 比の分離を示さずに, 白肉の ものが過剩になつたものと推察される。A系の後代に白が殆ど出なかつたの は，供試個體數が過少の爲に， $R^{f} R^{f}$ から $R^{f} r$ が出ても，rr は殆ど出なかつ た爲であらう。

元來易變因子の研究には各個體を夫火別々に自殖して，其の後代を追究すべ きであるが，ダイコンは自家不和合植物であり，同系繁殖による害も顯著にあ

（1）所罚肉は中心柱の肥大したもの 
らはれる爲に、乙の種の研究材料としては不適當である。かくて今可の研究も 紅心青因子の易變性に就んては，遲々として進捗せなかつた。從つて其の詳細 は向今後の努力に俟つとてろが甚だ多い。

\section{(4) 紅心青 $\times$ 白}

紅心羍 $A \times$ 四十日，紅心靑 $A \times$ 支那青，紅心靑 $B \times$ 大和白上り。

紅心青 $\mathrm{A} \times$ 四十日 $\mathrm{F}_{1}$ の根色は，外皮肉色共飞紫色（杜若色）であり，地上 部にも紫色を呈したが，色調の變異が多かつた。この外 $\mathrm{F}_{1} 150$ 個體中，5倜 體のみは白肉のものが出て來た。 $\mathrm{F}_{2}, \mathrm{~F}_{3}$ の分離は第 7 表の通りであつた。

第 7 表 紅心靑と白との雜種第 2,3 代

\begin{tabular}{|c|c|c|c|c|c|}
\hline 年次 & 雜 種 組 合 & 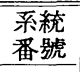 & $\begin{array}{l}\text { 紫肉王 } \\
\text { び赤肉 }\end{array}$ & 白肉 & 計 \\
\hline \multirow{3}{*}{$1934 \sim 1935$} & \multirow[t]{3}{*}{ 籸心青 $\Lambda \times$ 四十日 $\mathrm{F}_{2}$} & 1 & 72 & 33 & 105 \\
\hline & & 2 & 123 & 66 & 189 \\
\hline & & 3 & 24 & 13 & 37 \\
\hline \multicolumn{3}{|c|}{ 計 } & 219 & 112 & 331 \\
\hline \multirow[t]{3}{*}{1936} & 紅心青 $\mathrm{A} \times$ 四十日 $\mathrm{F}_{3}$ & $1 \sim 5$ & 52 & 32 & 84 \\
\hline & & $2 \sim 1$ & 14 & 5 & 19 \\
\hline & & $3 \sim 4$ & 115 & 54 & 169 \\
\hline \multicolumn{3}{|c|}{ 計 } & 181 & 91 & 272 \\
\hline \multirow[t]{3}{*}{$1936 \sim 1937$} & 紅心青 $\mathrm{A} \times$ 支那青 $\mathrm{F}_{2}$ & 1 & 153 & 40 & 193 \\
\hline & & 5 & 77 & 24 & 101 \\
\hline & & 6 & 90 & 21 & 111 \\
\hline \multicolumn{3}{|c|}{ 計 } & 320 & 85 & 405 \\
\hline \multirow[t]{2}{*}{$1938 \sim 1939$} & \multirow[t]{2}{*}{ 籸心青 $\mathrm{B} \times$ 大和白上り $\mathrm{F}_{2}$} & 4 & 165 & 69 & 234 \\
\hline & & 7 & 103 & 41 & 144 \\
\hline \multicolumn{3}{|c|}{ 計 } & 268 & 110 & 378 \\
\hline
\end{tabular}

第 7 表によれ ば，紅心靑 $A \times$ 四十日 $\mathrm{F}_{2}, \mathrm{~F}_{3}$ の成績は, 紫肉 及び赤肉 2 : 白 肉 1 比の分離次 近い。紅心青 B ×大和白上り $\mathrm{F}_{2}$ 分離 8 , 乙れ 之略々同樣の成 績を示した。か <3:1 比の代 りに2:1比を 示したのは, $R^{f}$ $\rightarrow r$ 八因子轉 化の爲之考へら

れる。紅心青 $\mathrm{A} \times$ 支那靑 $\mathrm{F}_{1}$ の根色は, 上記の場合之略々同樣であつた。然し $\mathrm{F}_{1} 49$ 個體は何れ紫肉で，白肉を生じなかつた。 $\mathrm{F}_{2}$ の分離は第 7 表に示せ る如く紫肉及び赤肉對白肉が $3: 1$ 比に近くなつた。又是等の中には，特に紅. 心靑 $\times$ 四十日の組合せに於ては，時とすると蕉に紫色と綠色との美しいモザイ クを示せるものが觀られた。又根も白色に細い紫色の部分キメラを示せる個體 
が存在した。これは體細胞突然變異によるものである。か」る事實よりすれ ば，約心赤×四十日の $\mathrm{F}_{2}, \mathrm{~F}_{3}$ 亿於て，たとへ根の肉色が白であつても，地上

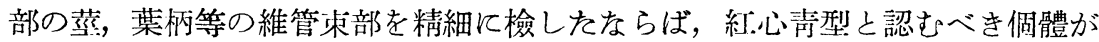
混在して居たとと〉想像される。

\section{（5）紅心青 $\times$ 赤}

赤四十日 $\times$ 紅心青 $A ，$ 紅心青 $\Lambda \times$ 赤四十日，(紅心青 $\Lambda \times$ 赤四十日） $\times$ 赤四十日。

赤四十日 $\times$ 紅心猄 $\mathrm{A}$ の $\mathrm{F}_{1}$ 壮，根の外皮赫紅梅色)，肉色必赫(薄色)であ つたが，紶心蔀の親よりは淡かつた。葉柄や中肋も赫色（淺蘇芳）を帶びて居 たが，變䀧が甚だしかつた。勿論維管束部斥赤色を呈して居た。ての外 $\mathrm{F}_{1} 150$

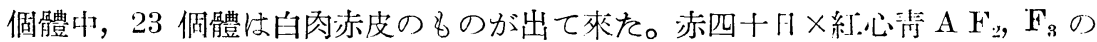
分離は第 8 表の通りであつた。

笨 8 表 赤と紅心青との雜種笴 2,3 代

第 8 裴による

\begin{tabular}{|c|c|c|c|c|c|}
\hline 作 次 & 雜 種 組 合 & $\begin{array}{l}\text { 系統 } \\
\text { 番踥虎 }\end{array}$ & 赤肉 & $\begin{array}{c}\text { 香肉 } \\
\text { (赫) }\end{array}$ & 战 \\
\hline \multirow[t]{2}{*}{$1934 \sim 1935$} & \multirow[t]{2}{*}{ 赤四十川×紅心静 $A F_{2}$} & 2 & 45 & $24(4)$ & 69 \\
\hline & & 6 & 47 & $|24(4)|$ & 71 \\
\hline \multicolumn{3}{|c|}{ 計 } & 92 & $48(8)$ & 140 \\
\hline 1936 & 赤叫十山 $\times$ 紅心考 $\mathrm{A} \mathrm{F}_{3}$ & $2 \sim 1$ & 56 & $28(1)$ & 84 \\
\hline
\end{tabular}
之, 赤肉 2 : 白 肉(赤皮) 1 比に 近い。乙の關係 は前述の紅心青 ×白の場合と似 て居る。郎ち肉

色白，外皮赤の個體と思つたもの」中にも，地上部を精烃すれば, 赤肉中に入る べきものがあつたと思はれる。向表中括弧內數字は白肉赤皮のもの小中，外皮 の赤色が極めて淡く，葉柄や中肋の赤色が顯著にあらはれた個體の數である。 紅條×赤四十日の場合に論じを樣に，乙れは赫と看做すべきもので，決して 白でないと確信する。

次飞紅心靑 $\Lambda \times$ 赤四十日の $\mathrm{F}_{1}$ の根色は，前述の夫之同樣であつた。乙の場 合も $\mathrm{F}_{1} 60$ 個體中，1 個體のみは白肉赤皮のものが出て來た。 $\mathbf{F}_{2}$ 分離に於て は，上記の點江注意し，靑頸赤肉 (紅心青型)，赤皮赤肉 $\left(\mathrm{F}_{1}\right.$ 型), 赤皮白肉(赤 四十日型)に分けて調査した。其の結果は第 9 表の通りであつた。

第 9 表によれば，青頸赤肉 $1:$ 赤皮赤肉 $2:$ 赤皮白肉 1 比の分離と思はれ 
第 9 表 紅心青と赤との雜種第 2 代 (1936～1937)

\begin{tabular}{|c|c|c|c|c|c|c|}
\hline 雜 & 種 縕 合 & $\begin{array}{l}\text { 系統 } \\
\text { 番號 }\end{array}$ & 觢䫫赤肉 & 赤皮赤肉 & 赤皮白肉 & 誩 \\
\hline \multirow[t]{2}{*}{ 紅心简 } & $\mathrm{A} \times$ 赤䧃十川 $\mathrm{F}_{2}$ & 1 & 50 & 127 & $93(14)$ & 270 \\
\hline & & 2 & 63 & 99 & $49(5)$ & 211 \\
\hline \multicolumn{3}{|c|}{ 計 } & 113 & '226 & $142(19)$ & 481 \\
\hline \multicolumn{3}{|c|}{$1: 2: 1$ としての理論數 } & 120.25 & 240.50 & 120.25 & \\
\hline
\end{tabular}

第 10 表（紅心青×赤四十日） $\mathrm{F}_{1}$ と赤四 十日との㞔雜種 (1936)

\begin{tabular}{|c|c|c|c|c|c|c|}
\hline 雜 & 種 & 組 & 合 & $\begin{array}{l}\text { 赤肉 } \\
\text { (赤皮) }\end{array}$ & 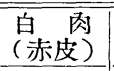 & 計 \\
\hline \multicolumn{4}{|c|}{ （籸心青 $\Lambda \times$ 赤四十日）×赤㚈十日 } & 202 & $220(1)$ & 422 \\
\hline \multicolumn{4}{|c|}{$1: 1$ としての理論數 } & 211 & 211 & \\
\hline
\end{tabular}

る。この組合せ に名稀に美しい モザイク個體が 觀られた。この $F_{1}$ 亿赤四十日 を厌卒雜した結 果は，柴肉（赫 皮)對白肉(赤皮)を $1: 1$ 比に分離した(第 10 表)。 以上の成績によれば紅 心靑に關與する选傳子 $R^{f}$ は，赤に關與する遗

傳子 $R$ 亿對し等位にあるものと考へられる。何んとなれば $\mathrm{F}_{1}$ の根色は赤皮赤 肉となり，两親の形質の總和であり， $\mathrm{F}_{2}$ 岵青项浾肉 $1:$ 赤皮赤肉 2 : 赤皮白肉 1 比行分離したからである。又 $\mathrm{F}_{1}$ 外外皮肉期赤色で紫色ではなかつをか ら，紅心青及び赤四十日には，其に $B$ 遭傳子が存せないものと思はれる。

\section{（6）約心靑 $\times$ 紅條}

紅心青 $A \times$ 紅條，紅條×紅心靑 $B$ 。

紅心靑 $A \times$ 紅條の $F_{1}$ 亿於ては，根の外皮が淡紫色の地色飞紅條樣の紫條を 有し，肉色紫のものから，外皮濃紫色で肉色紫のものまで，種々の變異が觀ら れた。乙の外 $\mathrm{F}_{1} 145$ 個體中 9 個體は，紅條白肉のものが出て來た。 $F_{2}, F_{3}$ の 分離は第 11 表の通りであつた。佮 $\mathrm{F}_{2}$ の 1 個體の根部に於て，美しい紫色之 白色の部分キメラを示せるものが觀られた。

第 11 表によれば，紫肉及び赤肉 3 : 白肉（紫條及び赤條） 1 比の分離と思 はれる。然るに紅條×紅心靑 $\mathrm{B} \mathrm{F} \mathrm{F}_{2}$ の分離は，紫肉及び赤肉 2 : 白肉 1 比飞近 レ。この $\mathrm{F}_{2}$ 中には美しんモザイク個體があつた。少括弧內數等は根部の紫條 甚だ淡く，一見白を思はせる個體數である。然し火等も葉柄には紫條を認め得 たから，白ではないと考へられる。

是等の場合も恐らく紅心青に關與する造傳子 $R^{f}$ は, 紅條關與する遺傳子 
第 11 㤗 紅心青と紅條との雜種第 2,3 代

\begin{tabular}{|c|c|c|c|c|c|}
\hline 年 次 & 雜 種 組 合 & $\begin{array}{l}\text { 系統 } \\
\text { 番號 } \\
\end{array}$ & $\begin{array}{l}\text { 紫肉及 } \\
\text { છ゙赤肉 }\end{array}$ & $\begin{array}{l}\text { 香肉 (紫條 } \\
\text { 隻び赤) }\end{array}$ & 計 \\
\hline \multirow[t]{2}{*}{$1934 \sim 1935$} & \multirow[t]{2}{*}{ 紅心青 $\mathrm{A} \times$ 紅條 $\mathrm{F}_{2}$} & 1 & 71 & 21 & 92 \\
\hline & & 2 & 40 & 9 & 49 \\
\hline \multicolumn{3}{|c|}{ 計 } & 111 & 30 & 141 \\
\hline \multirow[t]{3}{*}{1936} & \multirow[t]{3}{*}{ 籸心静 $\mathrm{A} \times$ 紅保 $\mathrm{F}_{3}$} & $1 \sim 2$ & 15 & $5(1)$ & 20 \\
\hline & & $1 \sim 3$ & 30 & 17 & 47 \\
\hline & & $2 \sim 5$ & 7 & 1 & 8 \\
\hline \multicolumn{3}{|c|}{ 計 } & 52 & $23(1)$ & 75 \\
\hline \multirow[t]{2}{*}{$1938 \sim 1939$} & \multirow[t]{2}{*}{ 紅條 $\times$ 粌心赫 $\mathrm{B} \mathrm{F}$} & 4 & 87 & $40(4)$ & 127 \\
\hline & & 7 & 90 & $71(6)$ & 161 \\
\hline \multicolumn{3}{|c|}{ 計 } & 177 & $111(16)$ & 288 \\
\hline
\end{tabular}

$R^{s}$ に對して等 位にあるものと 推察される。 紅條 $\times$ 紅心靑 $\mathrm{B} \mathrm{F}_{1}$ 個體中に は，美し々紅枝 と綠枝とのモザ イク個體があつ そので，紅枝及 び綠枝を别くに 自殖して其の次 代を育成した。

第 12 㳖 紅條と紅心青との雜種第 1 代の紅枝 及び綠枝自殖成績 (1938～1939)

\begin{tabular}{|c|c|c|c|c|c|c|}
\hline \multirow{2}{*}{$\frac{\text { 襍 }}{\text { 籸條 } \times}$} & \multirow{2}{*}{$\begin{array}{r}\text { 種 } \\
\text { 类青 }\end{array}$} & 組 & 苓 & \multicolumn{2}{|c|}{ 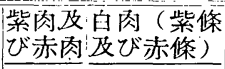 } & \multirow{2}{*}{$\frac{\text { 計 }}{136}$} \\
\hline & & $F_{1}$ & 枝自殖 & 70 & $66(9)$ & \\
\hline 籸條 $\times$ & 心青 & $F_{1}$ & 枝自殖 & 110 & $106(16)$ & 216 \\
\hline
\end{tabular}

其の成績は第 12 表の通 りであつた。

第 12 表によると，紅: 枝自殖次代に於ては，豫 期の如く，紫肉及び赤肉

個體と白肉個體とを得た。然るに綠枝自殖次代に於ては，白肉個體のみを生す るものと豫期されたのに意外にも，紫肉及び赤肉個體と白肉個體とを得た。乙 れによると，外觀上綠枝之思つたのは，實は紅枝であつたものと考へられる。

(7) 紅心声 $\times$ 紫

Purple Globe×紬心青 B

ダイコンの根色には固定した紫色のものが得られないから，乙の組合せと於 てはハツカダイコンの紫色品種 Purple Globe と紅心青 $B$ とを交雜しを。 Purple Globe の遺傳子型は $R R B B$ であるととが知られて居るから(簐者1938), てれと紅心靑とを交雜して，前記の糽心青と赤との交雜結果を確めんとしたの である。ての組合せの $\mathrm{F}_{1}$ は根の外皮濃紫色(桑染色), 肉色紫色であつた。 $\mathrm{F}_{2}$ の分離は第 13 表の通りであつた。

第 13 表によれば紫肉及び赤肉 2 : 白肉（紫皮及び赤皮） 1 此の分離と思は. 
第 13 表 紫と紅心青との雜種第 2 代 (1937～1938)

\begin{tabular}{|c|c|c|c|c|}
\hline 雜 種 組 合 & $\begin{array}{l}\text { 系統 } \\
\text { 番號 }\end{array}$ & $\begin{array}{l}\text { 紫肉及 } \\
\text { |゙赤肉 }\end{array}$ & 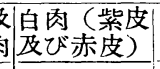 & 計 \\
\hline \multirow[t]{2}{*}{ Purple Globe $\times$ 紅心青 $\mathrm{B}$} & 1 & 86 & $44(8)$ & 130 \\
\hline & 2 & 35 & $18(3)$ & 53 \\
\hline \multicolumn{2}{|l|}{ 計 } & 121 & $62(11)$ & 183 \\
\hline
\end{tabular}

れる。少表中括弧內數 字壮, 外皮の紫色が非 常に淡く白を思はせる 個體數である。然し是 等も地上部は明膫飞紫 色を呈したから，沈し

て白でないと考へられる。

以上の成績は， $B$ 遺傳子の作用を除外すれば，紅心靑に對する紫の關係は， 赫の夫とよく一致するととを示す。

\section{3. 考}

察

\section{（1）赤色色素の發現と色原質}

永井氏（1921）によると，方領大根の根及び葉中には，色原質に就いて氏の 所謂 $\mathrm{F}$ 及び $\stackrel{(2)}{\mathrm{P}}$ の類似の 8 の共に 含有されて 居るといふ。筆者名犋て紅條及び 聖護院の根の外皮を，アムモニヤ蒸氣で處理したとてろ，淡黄色に變んずるの を觀た。從つて色原質としてのフラヴォンの存するてとは明らかである。今包 供試品種の根頸部外皮，根身部外皮，及び葉柄飞各らアムモニヤの蒸氣を作用 させ，色原質としてのフラヴォンの分布狀態を檢した。一部の成績は第 14 表 に示す通りであつた。表中十といふのは反應明膫なもので，士は不明瞭なも の,一は反應が認められないものである。

第 14 表 ダィコンに於ける色原質の分布

\begin{tabular}{|c|c|c|c|}
\hline 品 種 名 & 根頸部外皮 & 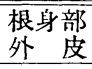 & 葉 \\
\hline 大和白上り &,,+ \pm- & - & + \\
\hline 美 濃 早 生 &,+ \pm & - & + , \\
\hline 聖＼cjkstart護 & + &,- \pm & + \\
\hline 重 & + & - & + \\
\hline 無 &,,+ \pm- & - &,+ \pm \\
\hline
\end{tabular}

第 14 表によると，一部 を除き，何れの品種女根頸 部外皮にはフラヴォンを有 するが，根身部外皮にはて れを缺くこと。又葉柄は， 一部を除き, 何れもフラヴォ ンを有するととが分かる。

この色原質の分布は，赤×白の $\mathrm{F}_{1}$ の色調，即ち根頸部は赤紫色であるが，下

（1）或 flavones 及び flavonols の glucoside を含む

（2）其の化學的性質末だ不明のもの(永井氏 1921 による) 
部は淡色となるとと，葉杯は明らかに沙紫色を呈する事䔈とよく一致する。更 に大和白上りや㭙無の根镇部外皮には，フラヴォンを有せない個體のあるてと が知られる。

第 1 報に記載した如く，滿洲約圓 $\times$ 大和肖上りの $\mathrm{F}_{1}$ は，根项部 は淡綠色 で，赤色は进だ淡く不明膫であつた。然し某柄中肋の赤紫色は，可なり顯著で あつた $\mathrm{F}_{2}$ に於ても根の赤色の分離は不明瞭で，少數赤根の倜體が出たに過 ぎなかつたが，某柄中肋の赤色は明らかな分離を示した。然るに春播にかるる $\mathrm{F}_{3}$ 飞於ては, 根の赤色の分離も可なり明瞭で，葉柄中肋の赤色と笔全に相關 して居るてとを知つを。かくて當時は只某柄中胁の亦色の分離のみを考慮し， 根色の遗傳の解釋は，不可解を現象として未解沁のま〉殘された。今其の根色 の分離を表示すると第 15 表の通りである。

第 15 表 赤と白との雜種第 2,3 代

\begin{tabular}{|c|c|c|c|c|c|}
\hline 年 次 & 雜 種 組 合 & $\begin{array}{l}\text { 系統 } \\
\text { 番號 }\end{array}$ & 赤 & 白 & 計 \\
\hline \multirow[t]{2}{*}{1934} & \multirow[t]{2}{*}{ 滿洲紅圆 $\times$ 大和白上り $\mathrm{F}_{2}$} & 1 & 18 & 69 & 87 \\
\hline & & 2 & 40 & 79 & 119 \\
\hline \multicolumn{3}{|c|}{ 尌 } & 58 & 148 & $2 \lessdot 6$ \\
\hline \multirow[t]{2}{*}{1936} & \multirow[t]{2}{*}{ 渋洲紅国 $\times$ 大和白上り $\mathrm{F}_{3}$} & 1 & 133 & 42 & 175 \\
\hline & & 2 & 157 & 44 & 201 \\
\hline \multicolumn{3}{|c|}{ 計 } & 290 & 86 & 376 \\
\hline
\end{tabular}

第 15 表による と, 根色の $\mathrm{F}_{2}$ 分 離の實數は赤 58 : 白 148 であり， $\mathrm{F}_{\mathbf{3}}$ は正常の單性雜種 比行近的。偶了今 包赤四十日 $\times$ 時無 の $\mathrm{F}_{1}$ に於ても,

根頸は淡綠色で，一部の倜體に於て赤紫色の,痕跡を止めるに過ぎないが，葉柄

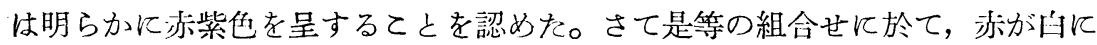
對して劣性の如き行動をとるのは如何をる理由によるものであらうか。以下一 試案として，些か杽强附會の感はあるが，篗者の管見を述べよう。

今色原質飞關與する遙傅子を $C$ と假定しよう。赤色色素の發現にはての色原

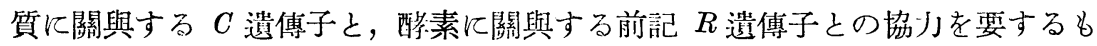
のと考へられる。前年供試した滿洲紅圓の遺傳子型は $C C R R$ であり，大和白 上りの夫は $c c r r$ であつたと假定すれば，其の $\mathrm{F}_{\mathrm{J}}$ は $C c R r$ であらう。而して 其の際赤色色素の發現に壮， $C$ と $R$ との間に特殊の量的關係が存在し，本來な らば當然赤色を生ずべ $\mathrm{F}_{1}$ の $C c R r$ は，色素の充分なる發現が困難であり， 
$C C R r, C c R R$ 及び $C C R R$ 亿於て始めて色素が發現されるものと假定すれば， 上記の謎を一應解き得る樣に考へられる。郎ちての假定に從へば， $\mathrm{F}_{2}$ に於ては 赩 5：白色 11 の分離比となり，實驗數によく合致する。更に $\mathrm{F}_{3}$ に於て赤 色個體が多く出たのは，當時不用意にも， F 2 個體中秒〉亦色色素を有する㛾體 $C C R r$ ，又は $C c R R$ を自殖したものと考へられる。䅛て KAJANUS 氏 (1912， 1913)はスウxーギンカブ (Brassica Napus) に就いて研究し，根の亦色は緑色 に對して優性であるが，一部に告色が綠色に對して劣性の如く行動する組合せ のあることを報告して居る。恐らく同氏の場合も上記の如き關係にあるのでは なからうか。

又第 1 報に於て考慮した樣に，春播のもの〉根の赤色色素の發現が，秋播の もの小头に比し一曆明瞭なる事實は，他の組合せに於ても篗者が屢 遭遇せる とてろであつて，乙れは春季の高溫が關係して居るものではないかと推察され る。郎ち秋播は成育中次第に低溫となるに反し，春播は成育の進むにつれて高 溫となり，色素の發現に好都合なのではあるまいかっ。

( 2 )紅心债について

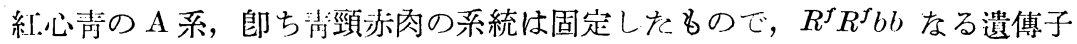
型を有するものと考へられる。てれを自殖しても殆ど白を生じなかつたのは， 供試個體數が過少の爲に， $R^{f} R^{f}$ からは $R^{f} r$ を生じてb，殆に゙ $r \boldsymbol{r}$ を生じなか つたものと思はれる。乙れに反してB系,師ち外皮肉とも紫色の系統は, $R^{f} r B b$ なるへテロのもので, 自殖後代に於て赤肉: 白肉を $2: 1$ 又は $1: 1$ 比に近く分 離した。かく白肉を過多に生じたのは， $R^{s \rightarrow r}$ への因子轉化により，過剩の $r r$ の倜體を生じをものと思はれる。A 系と白との雜種 $\mathrm{F}_{1}$ が，B系と同じ色調を 呈するととによつても，乙れは確かな事實であると信んずる。

宗，今非及び寺澤 3 氏（1919）によれば，根部紅色，族葉部暗紫色，花莖紅紫 色の紅心靑一系統の自然授粉の子孫は，根部紅色 ${ }^{2} 25$ ：白色 48 亿分離した。更 に紅色のもの১中にも，着色並びに濃度には種々の型のものを含んで居を。其 の中紬色個體を自花（又は隣花）授粉すると，次代は紅.色 24：白色 21 と分離

（1）光線の强度も關係!てて居るかも知れない

（2）筆者の赤肉を意味する 
し，白色個體の自殖次代は白色に固定した。次に明瞭なるモザイク個體の紅:色 枝を自殖した結果は, 紅色個體 5 : 白色個體 3 の分離を得, 白色枝の後代は白 色個體に固定したと報じて居る。ての記載によると氏等の供試系統は，篗者の $\mathrm{B}$ 系，郎ち $R^{f} r B b$ なる遺傳子型のものであつたと思はれる。更に氏等子紅心 青 $\times$ 春福の $\mathrm{F}_{1}$ に於て, 紅: 白を殆ど $1: 1$ 比に得を。其の紅色個體には色調 に種々の濃度のものを生じたから, 蕉部の着色濃度により4階級に分かち, 夫 夫隣花授粉並びに白色個體との交雜を行つた。其の結果は, 蕉部の着色濃度强 きものよりも，寧ろ淡色なものょ方が，紅色個體を生ずる割合多き事實を指摘 した。てれは濃度强きものが，ヘテロなるてとを示唆して居るものと思はれ る。更に氏等は紅心青 $\times$ 白の $\mathrm{F}_{1}$ て於て，紅色個體對白色個體を $1: 2$ 亿近い 此に得をと報じて居る。これも紅心青の供試系統が $R^{f} r$ のものであり， $R^{f \rightarrow r}$ への因子轉化の第に，かく過剩の白を生じたものであらう。篗者も紅心 靑 $\mathrm{B}$ 系 $\times$ 大和白上りの $\mathrm{F}_{1}$ 亿於て，赤肉 58 : 白 57 を，紅心青 $\mathrm{B}$ 系 $\times$ 紅條の $\mathbf{F}_{1}$ 飞於て，赤肉 12 : 白肉(紅條) 18 を，及び紅心青 B 系×赤聖 $\mathrm{F}_{1}$ に於て， 赤肉 21 : 白肉(赤皮) 24 を得た。又紅心青 $A$ 系と他色との組合せの $\mathrm{F}_{1}$ に 8 ， 少數白肉のものを生じたととは前述の如くである。

紅心靑×白の $\mathrm{F}_{2}$ に於て，組合せによつては白が過剩に出て來たが，てれは

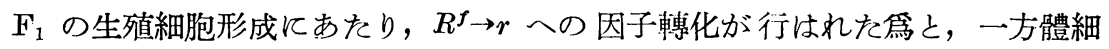
胞突然變異により，地上部の維管束部に赤色色素を有するもので，根の肉色が 赤より白に轉化した個體の生じた爲と解せられる。紅心靑 $\times$ 赤, 及び紅心靑 $\times$ 紫の $\mathrm{F}_{2}$ に於て赤肉個體の分離比の低い組合せの生じたのも, 同樣の理由によ るものであらう。又紅心靑と他色との交雜の後代に於て, 時として美しいモザ イク個體の生ずるととは前述の通りである。紅條×紅心靑 $\mathrm{B} \mathrm{F}_{1}$ のモザイク個 體につき，紅枝，綠枝を別々に自殖した結果は，外觀綠枝と思はれるものも䔬 の綠枝でなく，紅枝であると考へられる成績を得た。Purple Globe×紅心靑 B $\mathrm{F}_{1}$ のモザイク個體につき, 綠枝と思はれるもの小維管束部を檢したとてろで も, 夫は紅枝であるてとを知つた。從つてての點は份今後一層精細に檢討せね ばならなん。

（1）綠色枝を指するのであらら 
以上によれば紅心靑に關與する $R^{f}$ 瀢傳子は易變因子であり， $R^{f \rightarrow r}$ へ轉化 する場合のあるてとが分かる。併し其の易變性に關しては侩今後の研究に俟つ ところが甚だ多い。

\section{（3）根色の遺傳子型}

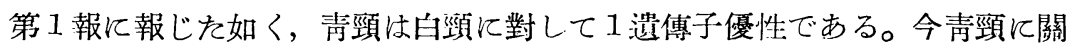
與する遺傳子を $G$ と假定しょう。アムモニヤ蒸氣に對する反應によつて判斷す れば，ダイコンの根锁外皮には大抵，花悲素發現に必要な色原質としてのフラ ヴォンが存在する。然し一部てれを缺く個體もあるととが分かつた。今色原質 に關與する遺傳子を $C$ と假定しょう。赤は白に對して優性で， $\mathrm{F}_{1}$ に於て赤紫 色をあらはし，Fに於て赤紫色 $9:$ 赤色 $3:$ 白色 4 比飞分離した。從つて 2 個 の遗傳子が假定される。一つは赤色に關與する $R$ 遺傳子で，他は單獨では色を あらはさないが， $R$ と其存すると告紫色をあらはす作用ある $B$ 遺傅子である。 紅條は白に對して 1 遗傅子優性であつたから， $R^{s}$ 遺傳子の支配を受けるもの と思はれる。紅條と赤との交雜に於ては， $R^{s}$ と $R$ とが等位にあり， $\mathrm{F}_{2}$ に於て $1 R R: 2 R R^{s}: 1 R^{s} R^{s}$ 比の分離が得られた。紅心奨飞關與する遗傳子 $R^{f}$ は一 種の易變因子である爲に $\left(R^{f \rightarrow r}\right)$, 他色との交雜 $\mathrm{F}_{2}$ 分離はや〉亂された。紅 心青×白の交雜に於ては，紅心声關與する $R^{f}$ 遗傳子のみを考慮すれば，白

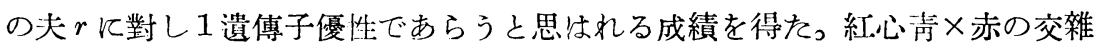
に於ては， $R^{f}$ は $R$ と等位にあり，又紅心青×紅條の交雜に於ても， $R^{f}$ は $R^{s}$ 飞對して等位にあるもの」如く，何れも $\mathrm{F}_{2}$ に於て單性雜種比之思はれる分離 を示した。最後に紅心表メ紫の交雜に於ては, 紫の遺傳子型が $R R B B$ である から，B遗傳子の作用を度外視すれば，紅心靑×赤の組合せと全く同樣の結果 が得られた。

以上の成績より考察すれば， $R^{f}, R^{s}, R$, 及び $r$ 愎對立因子 (multiple allelomorphs) の一組を構成するものと思はれる。そして火等は次の優劣關係にあ るのであらう。 $R^{f}=R^{s}=R>r$.

筆者（1938） は震にハツカダイコンの根色の遺傳を研究し, 黑, 黃, 及び白 に於て $Y^{b}, Y$, 及び $y$ は複對立因子を構成するものと考へた。從つてRaphanus 、は根色關し， $R$ 及び $Y$ 及 2 つの複對立因子系が存するものと思はれる。 
KELLER 氏(1936)\& Beta の根色飞於て，赤色色素關與する邀傳子 $R, R^{t}$,

$r$, 黃色色素に關與する选傅子 $Y, Y^{r}, y$ が火々褑對立因子を構成する由を報告 した。

以上記すところによつて考察すれば，ダイコンの根色の遦傅子型は略ら第 16 装の如き为のであらう。

第 16 裴 根色の遗傳子型

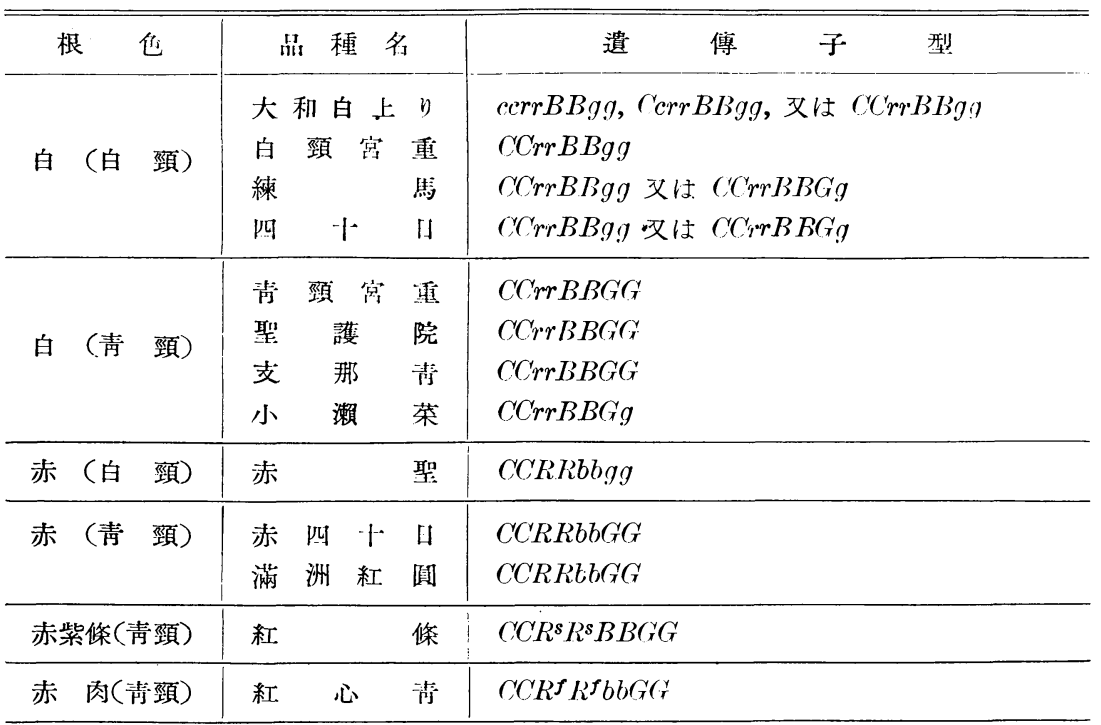

4. 摘 要

1. 赤 $\times$ 白の $\mathrm{F}_{1}$ は赤紫色で， $\mathrm{F}_{2}$ 及び $\mathrm{F}_{3}$ の分離は，赤紫色 $9:$ 赤色 3 : 白色 4 比であることが判明した。

2. 紅條と赤との交雜に於ては， $\mathrm{F}_{1}$ は赫紅條で， $\mathrm{F}_{2}$ は赤 1 : 赤紅條 2 : 紅.

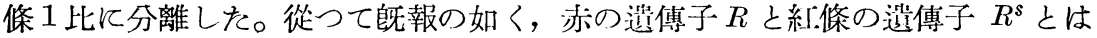
等位にあるものと考へられる。

3. 約心青に關與する腎傳子 $R^{f}$ は易變因子であつて，屢っ白 $r$ へ轉化を 示す $\left(R^{f} \rightarrow r\right) 。$

4. 紅心青 $\times$ 白の $\mathrm{F}_{1}$ は，根の外皮，肉共飞紫色であり， $\mathrm{F}_{2}, \mathrm{~F}_{3}$ に於ける肉 色紫及び赤 : 白の分離比は，略さ單性雜種比であらうと思はれた。 


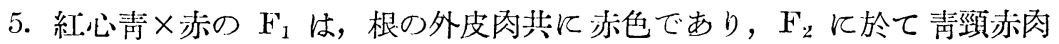
1 : 赤皮浾肉 2 : 赤皮白肉 1 比飞分離した。從つて紅心青に關與する遺傳子 $R^{f}$ は，赤に關與する遺傳子 $R$ 飞對し等位にあるものと考へられる。

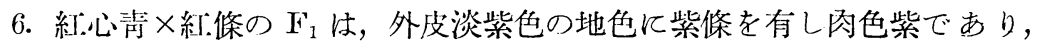
$\mathrm{F}_{2}, \mathrm{~F}_{3}$ 飞於け万紫肉及び赤肉：白肉(紫條及び柴條)の分離比は，略了單性雜 種比であらうと思はれた。從つて $R^{f}$ と $R^{s}$ 女等位にあるものと推察される。

7. 紫×紅心靑の $\mathrm{F}_{1}$ は，根の外皮，肉色共に紫色であり， $\mathrm{F}_{2}$ 亿於ける紫 肉及び赤肉：白肉（紫皮及び赤皮）の分離比は，略子單性雜種比であらうと思 はれた。

8. 以上の成績により考察すれば， $R^{f} ， R^{s}, R$, 及び $r の$ 各遗傳子は，複對立 因子の一組を構成するものと思はれる。そして火等は下の優劣關係にあるので あらう。 $R^{f}=R^{s}=R>r$.

\section{（大阪府三島郡苂木町）}

\section{引 用 文 献}

星加賀美 1938： 大根に於けるアルビ>の遺傳. 農學論譵 201〜206

Iir AI, Y., 1934: On the mutable genes of Pharbitis, with special reference to their bearing on the mechanism of bud-variation. Jour. Coll. Agr. Imp. Univ. Tokyo, 12 : 479-523

KaJanus, B., 1912 : Genetische Studien an Brassica. Zts. Ind. Abst. u. Vererbgsl., $6: 215-237$

KaJanus, B., 1913 : Über die Vererbungsweise giwisser Merkmale der Beta-und Brassica-Rüben. II. Zts. Pfl. Zücht., 1 : 419-463

KeLLER, W., 1936 : Inheritance of some major color types in beets. Jour. Agr. Res., $52: 27-38$

NAGAI, I., 1921: A genetico-physio'ogical study on the formation of anthocyanin and brown pigments in plants. Jour. Coll. Agr. Imp. Univ. Tokyo, 8: 1-92.

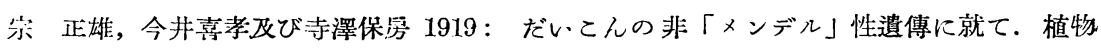
學雜誌 $33: 21 \sim 30$

建部民雄，1937：ダイコンの色の遺傳研究 (I). 植物及動物 5：1301〜.1308

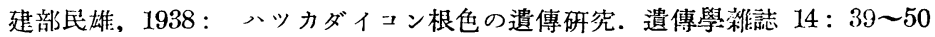




\title{
Studies on the Inheritance of Color in the Japanese and Chinese Radish (II)
}

\author{
Tamio Tatebe
}

(Résumé)

With respect to root color, the following genes may ba assumed : $G$ : a gene for pale green neck.

$C$ : a gene for flavones as chromogenic substance for the produetion of anthocyanins.

$R$ : a gene for the production of red pigment.

$B$ : a gene which produces no color alone, but acts in conjunction with $\mathrm{R}$ gene to produce purple pigment.

$R^{s}$ : a gene for red striping.

$R^{f}$ : a gene causing a red coloration of the vascular bundle in all parts of the plant. In the root this gene manifests red Aesh. $R^{f}$ gene is mutable, reverting to its recessive white $\left(R^{f} \rightarrow r\right)$.

Red flesh, red striping, red, and white are so related genetically that any two of them taken together give results conforming to a monogenic scheme. Consequently it seems probable that the gene for red flesh constitutes a set of multiple allelomorphs with three genes for red striping, red, and white.

The probable genotype of the root color may be represented as follows :

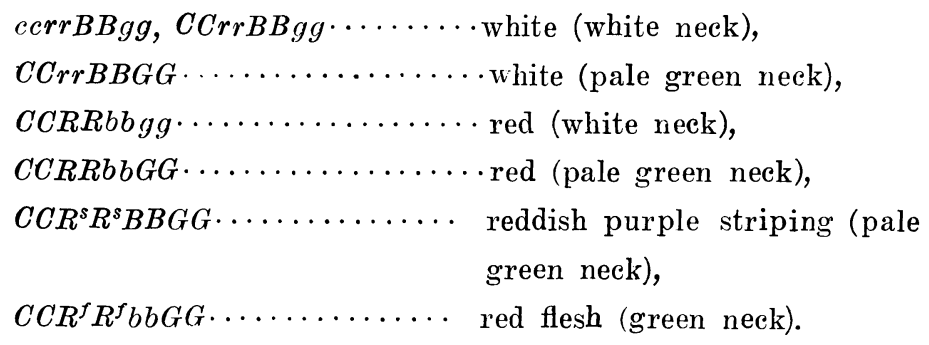

